\title{
THE RELATIONSHIP BETWEEN WORK ENVIRONMENT AND HORIZONTAL VIOLENCE AMONG STAFF NURSES AT PORT SAID GENERAL HOSPITALS
}

\author{
Mai Khaled El-Sayed Ahmed El-Deeb ${ }^{1}$; Prof. Samah Faisal Fakhry²; Dr. Marwa \\ Mohamed Abed-Aleem ${ }^{3}$ \\ Bacholar of Nursing, Port Foaud Hospital ${ }^{1}$; Professor of Nursing Administration,
} Faculty of Nursing, Ain Shams University ${ }^{2}$; Lecturer of Nursing Administration, Faculty of Nursing, Port Said University ${ }^{3}$

\begin{abstract}
Background:violence is considered one of the main challenges in nursing profession and all health sector organizations and might hinder them achieving such health work environment. Aim: the present study aimed to assess the relationship between work environment and horizontal violence among staff nurses at Port-Said general hospitals. Subjects and Method:Design:A descriptive correlational research design was used. Setting: port-said general hospital, El-Zhour general hospital and port-fouad general hospital. Subjects: A sample of 300 staff nurses working in above mentioned settings. Tools: Data were collected using two tools: Revised Nurse Work Index and Nursing Horizontal Violence Scale. Results:The study revealed that about three quarters $74.7 \%$ of nurses perceived their practice environment as average favorable environment, Slightly less than half of the sample reported that never exposure to horizontal violence. Conclusion:There was positive statistically significant correlation between horizontal violence and work environment and its subscales except working relationships between nurses and doctors' subscale. Recommendations: Establishing and enforcing implementrestricted ethical behaviors policies and procedures are very crucial to maintain zero tolerance environments related to horizontal violence.
\end{abstract}

Key words: Horizontal violence, Staff nurses, Work environment. 


\section{INTRODUCTION}

Creating healthy and safe work environment for health care providers is a major concern for healthcare employers (Pierre, 2014). Hence, Healthy work environment is imperative for ensuring patient safety, staff satisfaction, retention, and organization's financial viability (American association of critical care nurses, 2021). According to the Occupational Safety and Health Act (Aujla, 2012) organizations have a crucial responsibility in protecting their employees and in creating healthy work environment beyond basic moral principles

Work environment could be defined as nurses' perceptions about various aspects of their work climate (Vessey, Demarco \& Difazio, 2010). Akien, et al., (2001) conceptualized environment to be composed of five dimensions of: Nurse Participation, nursing foundation for quality of care, collegial nurse physician relation, nurse managers' ability, leadership and support, and staffing, and resources adequacy.

Every healthcare provider needs a positive work environment for his security and comfort. Healthy work environment considered an important element for achieving satisfaction of all workers in health sector, for effectiveemployment and retention, and for providing a good healthcare for patient and all customers, whilereaching a condition of health work environment; it is often challenged to think differently about culture, traditions and daily behaviors at work, Changing work environment and its implementrequires hard work and more time, alsoneeds a completeplan or strategy that includes physical, cultural, social and job design conditions (American association of critical care nurses, 2021).

Longo and Sherman, (2007) asserted that undesirable environmental workplace interactions may disturb employee's performance, producing a work climate of frustration and conflicts thatlead to burnout, turnover, low quality of carethat may be in an image of hostilityform staff nurse toward another of her colleague which named horizontal violence.

There are different names for horizontal violence, including lateral violence, horizontal hostility, bullying, aggression, and incivility (Attia, Abo Gad and Shokir, 2020) . (Labour.gov.on.ca. 2021) defined vertical-horizontal violence as a "violence by an individualtakes place vertically when manager in authority performs violence against his subordinatesat lower positions". 
Horizontal violence, also known as lateral violence, takes place amongemployees working in theequal levels or sameplaces. Horizontal violence is considered as hostile and aggressiveattitude by worker or team toward others (Bloom, 2018). The most commonindicators of horizontal aggression are not acts of obvioushostility but less affected psychologically aggressive actions, such as disseminationtales about and giving badexpressions to colleagues. Also nonverbal innuendos, verbal affronts, undermining behaviors, sabotage, infighting, scapegoating, backstabbing, lack of keeping confidentiality, and destroyedassurances are common manifestations. Practices of horizontal violence may also contain belittling or criticizing another workerin the presence of others, delayingor hiding an opportunity for promotion, and separating or isolatingone member of the groupfrom engaging in activities or celebrations (Taylor, 2016).

Horizontal violence can be verbal or nonverbal. Hostility is "appeared in conflict, opposition, or resistance in thought or principle". Verbal harassment is "to annoy obstinately" or "to produce a nasty or aggressivebehavior, particularly by unwantedorundesirable verbal manner" (Bartholomew, 2006). Additionally,when an individualapplies or usesauthority or coercion in a way that causes the victim to senseoccurrence of a threat (Attia, Abo Gad \& Shokir, 2020). Monotonoushostile or violent behavior from an individual in administrative authority that resulted inemotional or psychologicaldamage and recurrentunpleasantactivitiescaused to person by another one (Thobaben, 2007).

\section{Significance of the study:}

Consequences of horizontal violence was identified in nursing literature for more than 20 years, however that violence stated from large time but it still have a gab in the research with the practice of nursing and occurrence among nursing personnel. The American Psychiatric Nurses Association (American association of critical care nurses 2021), stated that large number of professional nurses suffering from violence in the workplace which considered an occupational hazard that may occurred by patients, relatives or any other clients adding to them their colleagues. However, an interest has developed concerning the importance of creating and sustaining healthy work environment and its reflection on violence among nurses. Struggling violence and hostile attitudes are become an important role that must done by victims especially nursing staff through recognize standards and rules that directnursing practice in work environment 
and feel empowered to take actions against horizontal violence. Accordingly there is a need to understand the relationship between work environment and horizontal violence (Randle, 2003).

\section{AIM OF STUDY:}

\section{This study aim to:}

Assess the relationship between work environment and horizontal violence among staff nurses at Port Said general hospitals through:

\section{Research objective:}

1- Assessing work environment as reported by staff nurses at Port Said general hospitals.

2- Identifying horizontal violence among staff nurses at Port Said general hospitals.

3- Finding out The relationship between work environment and horizontal violence among staff nurses at Port Said general hospitals.

\section{Research Question:}

1- What is the work environment as reported by staff nurses at Port Said general hospitals?

2- Is there horizontal Violence among staff nurses at Port Said general hospitals?

3- Is there a relationship between work environment and horizontal violence among staff nurses at Port Said general hospitals?

\section{SUBJECTS AND METHOD :}

The technical design includes research design, setting, subjects and tools of data collection.

\section{Study design:}

Descriptive correlational research design was used to detect the relation between work environment and horizontal violence.

\section{Study Setting:}

The present study was carried out in the main three governmental hospitals; namely Port-Said General Hospital, Port-Fouad General Hospital and El-Zehour General Hospital in Port-Said governorate affiliated to the ministry of health. 


\section{- Port Said General Hospital:}

The total hospital force is 171 staff nurses and bed capacity 157 bed.

\section{- Port-Fouad General Hospital:}

The total hospital force is 75 staff nurses and bed capacity 144 bed.

\section{- El-Zehour General Hospital:}

The total hospital force is 86 staff nurses.and Bed capacity 69 bed.

\section{Study subjects:}

The subjects of the study included all available staff nurses working in the previous mentioned settings and have at least one year of experience The sample size was 300 staff nurse out of the total study population that included 332 nurses

\section{Tools Of Data Collection}

Data of this study was collected using two different tools. These included Revised Nurse Work Index (NWI-R) and Nursing Horizontal Violence Scale.

\section{Tool (I): Revised Nurse Work Index (NWI-R)}

This tool consists of two parts:

Part 1: Self-administered questionnaire sheet: It included questions to collect data related to nurses' personal and job characteristics as age, educational level, staff nurses' experience years practice in nursing.

\section{Part 2: Revised Nurse Work Index (NWI-R)}

This scale was developed by Aiken and Patrician (2008) to measure the nurses' work environment. It consists of 28 items using a 3-point Likert type scale response ranging from "Agree" to "Disagree", covering five subscales namely: nurse participation (8 items), nursing foundation for quality of care ( 9 items), collegial nurse physician relationship (3 items), nurse manager ability, leadership and support (4 items) and staffing and resource adequacy (4 items).

\section{Scoring system}

Work climate score were computed by summing items, 3-point likert-scale of: agree (3), sometimes (2), disagree (1) whereas the minimum score was 28, while the maximum score obtainable was 84 . These scores were then transformed to percent equivalents of 
raw score. Nurses that scored $\geq 70 \%$ were grouped as having high quality work environment, 40-69\%, average quality work environment, and < 40\%, low work environment.

\section{Tool (II): The horizontal violence Scale}

This scale was developed by Winchester medical center (2011), to measure horizontal violence among nurses; it has included 12 items aimed to determine the occurrence with which nurse's observer HV. Also the occurrence of HV assessed through Likert scaleranging from never (1) to daily exposures to horizontal violence (6).

\section{Tools Validity:}

The intended tools of data collection were revised by the researcher and got supervisor's approval as the tool was previously translated into Arabic, and used on Egyptian and tested for its validity, and applicability

\section{Reliability of study tools:}

Cronbach alpha coefficient was calculated to assess the reliability of the tools through their consistency $(0.76)$

\section{Pilot study:}

A pilot study was carried out on "6" staff nurses and "24" staff nurses who represented $10 \%$ of the total sample, from El-Homeate hospital and El-Nasser hospital. The purpose of the pilot study was to test the applicability and feasibility of the study tools. Also it served to estimate the time needed to fill-in the questions, in addition to finding out any obstacles and problems that might interfere with data collection. The subjects who shared in the pilot study were excluded from the study subjects and completion of tools took 20-30 minutes for each tool.

\section{Field work:}

The data were collected from all staff nurses in the study settings using the questionnaire sheets. This process of data collection was carried out in the period from Mid June 2015 to end June 2016. The study tools were distributed to the selected subjects in their work setting by the researcher. Data were collected by the researcher from staff nurses in the morning shift and their nurses at five days per week in three shifts. While night shift, the questionnaires were obtained during the morning shift after explaining the objectives of the study and how to complete the tool. Some of the participants filled in the 
questionnaire sheets at the time of distribution, while others fixed another time to fill them. Data were collected by the researcher over 4 month's period.

\section{(III) ADMINISTRATIVE DESIGN:}

An official letter from the faculty dean of nursing will be sent to managers of previous mentioned hospitals to take formal agreement to carry out the study.

\section{Ethical Consideration:}

A brief explanation of the aim of the study was given to director, head nurses, and staff nurses in the study, stressing on confidentiality of the collected information to be familiar with the importance of their participation and it is only for the purpose of the study to take their formal agreement for included in the study. And they were informed about their right to refuse or to withdraw at any time.

\section{(IV) STATISTICAL DESIGN:}

\section{Statistical Analysis of the Data}

\section{Statistical Analysis:}

Data analysis was performed using IBM SPSS statistical software version 22. The data were explored. Descriptive statistics with mean, median and standard deviation (SD) for continuous variables and frequency for categorical variables were analyzed. Qualitative variables were compared using qui square test $\left(\boldsymbol{X}^{2}\right)$ as the test of significance and independent, (r) test was used to identify the relationship between two variables. The p-value is the degree of significance. A significant level value was considered when the $p$-value $\leq$ 0.05 and a highly significant level value was considered when the $\mathrm{p}$-value $\leq 0.001$, while the $\mathrm{p}$-value $>0.05$ indicates non-significant results.

\section{RESULTS:}

Table (1): Slightly more than half of the study subjects (58.7\%) aged between 20 to 35 years with the mean $34.5 \pm 10.02 \%$ years. In addition, more than two thirds of staff nurses $(67.3 \%)$ had nursing diploma. While, the least percentage $(0.6 \%)$ had master degree. Concerning, marital status the highest percentage $(67.0 \%)$ were married. While, the least percentage $(0.7 \%)$ were divorced. Finally, It was found that about half had nurses of $(52.7 \%)$ had1 to 15 years' experiencein nursing the with the Mean score $15.7 \pm$ 10.3 years.

Table (2):Demonstrates an average favorable work environment as reported by studied staff nurses in relation to all the five subscales (nurse participation, nursing 
foundation for quality of care, nurse manager ability, leadership and support, staffing and resource adequacy and collegial nurse- physician relationship) .Generally, regarding total score of all subscales, $74.7 \%$ of studied staff nurses reported an average favorable work environment.

Table (3): About two fifths of staff nurses have faced and exposedto sometime severely criticizing someone without having listen to both sides of the story and never complaining about co-workers about another membersas a replacement fortrying to manage theclashwith that person using open clear discussion $(41.0 \% \quad \& 41.7 \%$ respectively), More than one third (39.3\%)never experienced or witnessedmaking hurtful remarks to or about co-workers in front of others, More than half of nurses (51.0\%) never experienced or witnessed raising eyebrows or rolling eyes at another co-worker, and more than two fifths $(44.3 \%)$ imaginingto not to notice a co-worker.

Table (4): As table illustrated less than half of nurses reported that they are sometime toucheddispiriteddue to low constructivecriticism "feedback", also they never have a communication with co-workers. Moreover, less than two fifths sometime had physical symptoms such as inability to sleep, headaches, and abdominal pain because of poor interactions with certain co-workers.

Table (5): As table shows less than half of staff nurses were some time observed horizontal violence from unlicensed assistive personal, Supervisors, Physicians, and also anotherhealthcare professionals, and physicaltherapists. Moreover, less than two fifths some time observed negative behaviors fromhousekeeping, security, secretarial, maintenance.

Table (6): It was found that there was positive statistically significant correlation between horizontal violence and work environment and its subscales (Nurse participation, Nursing foundation for quality of care,Efficiency and lead managers of nursing and support nurses, and The adequacy of human resources and sources) exceptWorking relationships between nurses and doctors subscale. 
Table (1): Personal and job characteristics amongstudied staff nurses $(\mathrm{N}=300)$

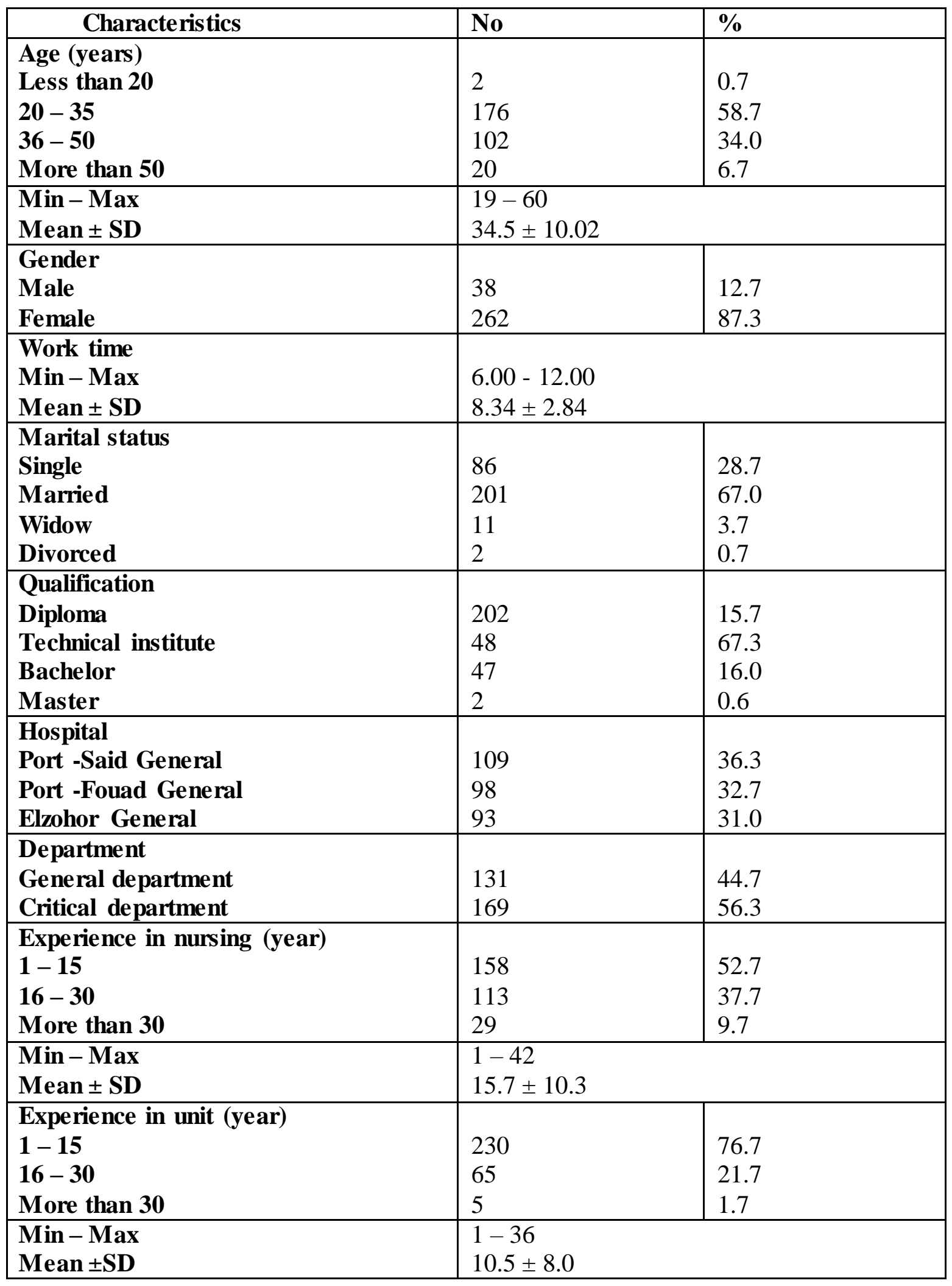


Table (2): Total score of work environment among studied nurses at Port-Said general hospitals $(\mathrm{N}=300)$

\begin{tabular}{|l|l|l|l|l|l|l|}
\hline \multirow{2}{*}{ Work environment } & \multicolumn{2}{l|}{ High } & \multicolumn{2}{l|}{ Average } & \multicolumn{2}{l|}{ Low } \\
\cline { 2 - 8 } & No & $\%$ & No & $\%$ & No & $\%$ \\
\hline Nurse participation & 19 & 6.3 & 186 & 62.0 & 95 & 31.7 \\
\hline Nursing foundation for quality of care & 26 & 8.7 & 218 & 72.7 & 56 & 18.7 \\
\hline $\begin{array}{l}\text { Nurse manager ability, leadership and } \\
\text { support }\end{array}$ & 0 & 0.0 & 229 & 76.3 & 71 & 23.7 \\
\hline staffing and resource adequacy & 0 & 0.0 & 161 & 53.7 & 139 & 46.3 \\
\hline collegial nurse physician relationship & 144 & 48.0 & 132 & 44.0 & 24 & 8.0 \\
\hline Total score & 13 & 4.3 & 224 & 74.7 & 63 & 21.0 \\
\hline
\end{tabular}

Table (3): Reported frequency of horizontal violence among staff nurses within the last year at Port Said General Hospitals $(\mathrm{N}=300)$

\begin{tabular}{|c|c|c|c|c|c|c|c|c|c|c|c|c|}
\hline & \multicolumn{2}{|c|}{ Never } & \multicolumn{2}{|c|}{ Once } & \multicolumn{2}{|c|}{ Sometimes } & \multicolumn{2}{|c|}{ Monthly } & \multicolumn{2}{|c|}{ Weekly } & \multicolumn{2}{|c|}{ Daily } \\
\hline & No & $\%$ & No & $\%$ & No & $\%$ & $\overline{\text { No }}$ & $\%$ & No & $\%$ & No & $\%$ \\
\hline $\begin{array}{l}\text { Harshly criticizing } \\
\text { someone without } \\
\text { having heard both } \\
\text { sides of the story }\end{array}$ & 114 & 38.0 & 42 & 14.0 & 123 & 41.0 & 12 & 4.0 & 2.0 & 0.7 & 7.0 & 2.3 \\
\hline $\begin{array}{l}\text { making hurtful } \\
\text { remarks to or } \\
\text { aboutco-workers }\end{array}$ & 118 & 39.3 & 49 & 16.3 & 113 & 37.7 & 5 & 1.7 & 6.0 & 2.0 & 9.0 & 3.0 \\
\hline $\begin{array}{l}\text { Raising eyebrows } \\
\text { or rolling eyes }\end{array}$ & 153 & 51.0 & 34 & 11.3 & 92 & 30.7 & 9 & 3.0 & 5.0 & 1.7 & 7.0 & 2.3 \\
\hline $\begin{array}{l}\text { Pretending not to } \\
\text { notice a co-worker } \\
\text { struggling with his } \\
\text { or her workload }\end{array}$ & 133 & 44.3 & 37 & 12.3 & 104 & 34.7 & 9 & 3.0 & 3.0 & 1.0 & 14.0 & 4.7 \\
\hline Total & 129 & 42.86 & 38 & 12.92 & 108 & 36.16 & 10 & 3.2 & 5 & 1.54 & 10 & 3.32 \\
\hline
\end{tabular}


Table (4): Reported frequency of horizontal violence among staff nurses within the last year at Port Said General Hospitals $(\mathrm{N}=300)$

\begin{tabular}{|c|c|c|c|c|c|c|c|c|c|c|c|c|}
\hline \multirow{2}{*}{$\begin{array}{l}\text { Answer these questions } \\
\text { from your perspective } \\
\text { point of view }\end{array}$} & \multicolumn{2}{|c|}{ Never } & \multicolumn{2}{|c|}{ Once } & \multicolumn{2}{|c|}{ Sometimes } & \multicolumn{2}{|c|}{ Monthly } & \multicolumn{2}{|c|}{ Weekly } & \multicolumn{2}{|c|}{ Daily } \\
\hline & No & $\%$ & No & $\%$ & No & $\%$ & No & $\%$ & No & $\%$ & No & $\%$ \\
\hline $\begin{array}{l}\text { Feeling ofdiscouragementdue } \\
\text { to lack positive feedback }\end{array}$ & 77 & 25.7 & 37 & 12.3 & 142 & 47.3 & 12 & 4.0 & 7 & 2.3 & 25 & 8.3 \\
\hline $\begin{array}{l}\text { hesitated to ask questions for } \\
\text { fear I'd be ridiculed }\end{array}$ & 132 & 44.0 & 44 & 14.7 & 110 & 36.7 & 4 & 1.3 & 2 & 0.7 & 8 & 2.7 \\
\hline $\begin{array}{l}\text { I've left work feeling bad } \\
\text { about myself because of } \\
\text { interactions with co-workers }\end{array}$ & 128 & 42.7 & 55 & 18.3 & 92 & 30.7 & 7 & 2.3 & 8 & 2.7 & 10 & 3.3 \\
\hline $\begin{array}{l}\text { Having physical symptoms } \\
\text { like inability to sleep, } \\
\text { headaches,and abdominal } \\
\text { painbecause of poor } \\
\text { interactions with certain co- } \\
\text { workers }\end{array}$ & 92 & 30.7 & 36 & 12.0 & 115 & 38.3 & 10 & 3.3 & 4 & 1.3 & 43 & 14.3 \\
\hline Total & 116 & 38.36 & 43 & 14.46 & 111. & 37.06 & 7.0 & 2.44 & 5 & 1.66 & 18 & 5.98 \\
\hline
\end{tabular}

Table (5): Frequency of observing healthcare workers exhibiting the negative behaviours among the staff nurses within the last yearat Port- Said general hospitals $(\mathrm{N}=300)$

\begin{tabular}{|c|c|c|c|c|c|c|c|c|c|c|c|c|}
\hline \multirow{2}{*}{$\begin{array}{l}\text { How often have you } \\
\text { observed the following } \\
\text { categories of Health care } \\
\text { providers practicing } \\
\text { negative behaviors? }\end{array}$} & \multicolumn{2}{|c|}{ Never } & \multicolumn{2}{|c|}{ Once } & \multicolumn{2}{|c|}{ Sometimes } & \multicolumn{2}{|c|}{ Monthly } & \multicolumn{2}{|c|}{ Weekly } & \multicolumn{2}{|c|}{ Daily } \\
\hline & No & $\%$ & No & $\%$ & No & $\%$ & No & $\%$ & No & $\%$ & No & $\%$ \\
\hline  & 104 & 34.7 & 48 & 16.0 & 132 & 44.0 & 1 & 0.3 & 5 & 1.7 & 10 & 3.3 \\
\hline $\begin{array}{l}\text { b-Supervisors } \\
\text { (directors,managers, } \\
\text { educators, charge } \\
\text { nurses) }\end{array}$ & 94 & 31.3 & 42 & 14.0 & 147 & 49.0 & 3 & 1.0 & 4 & 1.3 & 10 & 3.3 \\
\hline c-Physicians & 105 & $\begin{array}{l}35 . \\
0\end{array}$ & 44 & 14.7 & 132 & 44.0 & 4 & 1.3 & 2 & 0.7 & 13 & 4.3 \\
\hline d-Others & 115 & $\begin{array}{l}38 . \\
3\end{array}$ & 43 & 14.3 & 127 & 42.3 & 4 & 1.3 & 1 & 0.3 & 10 & 3.3 \\
\hline $\begin{array}{l}\text { e-Other staff (such as } \\
\text { housekeeping, security, } \\
\text { secretarial, maintenance) }\end{array}$ & 110 & $\begin{array}{l}36 . \\
7\end{array}$ & 46 & 15.3 & 115 & 38.3 & 10 & 3.3 & 3 & 1.0 & 16 & 5.3 \\
\hline Total & 106. & $\begin{array}{l}35 \\
2\end{array}$ & $\begin{array}{l}45 . \\
0\end{array}$ & $\begin{array}{l}14.8 \\
6\end{array}$ & $\begin{array}{l}130 . \\
0\end{array}$ & $\begin{array}{l}43.5 \\
2\end{array}$ & 4.0 & $\begin{array}{l}1.4 \\
4\end{array}$ & 3 & 1 & 12 & 3.9 \\
\hline
\end{tabular}


Table (6): Correlation between work environment and horizontal violence among staff nurses at Port-Said general hospitals $(\mathrm{N}=300)$

\begin{tabular}{|l|l|l|}
\hline \multirow{2}{*}{ Work environment } & \multicolumn{2}{l|}{ Horizontal violence } \\
\cline { 2 - 3 } & $\mathbf{R}$ & p-value \\
\hline Nurse participation & 0.294 & $0.000^{* *}$ \\
\hline Nursing foundation for quality of care & 0.141 & $0.01^{*}$ \\
\hline $\begin{array}{l}\text { Efficiency and lead managers of nursing and support } \\
\text { nurses }\end{array}$ & 0.369 & $0.000^{* *}$ \\
\hline The adequacy of human resources and sources & 0.322 & $0.000^{* *}$ \\
\hline Working relationships between nurses and doctors & 0.089 & 0.13 \\
\hline Total mean of work environment & 0.316 & $0.000^{* *}$ \\
\hline
\end{tabular}

${ }^{*} \mathbf{p} \leq \mathbf{0 . 0 5 * *} \mathbf{p} \leq \mathbf{0 . 0 0 1}$

\section{DISCUSSION:}

Creating health and safe work environment for health care providers is a major responsibility of healthcare organization (Pierre, 2014). Moreover; Healthy work environment had many positive results on patient safety, staff satisfaction, retention, and organization's status in markets. However, violence is considered one of the major challenges facing nursing profession and health care organizations and might hinder them achieving such health work environment (American association of critical care nurses 2021).

This study was conducted to assess the relationship between work environment and horizontal violence among staff nurses at Port-Said general hospitals, the study was conducting on 300 staff-nurses more than half of them aged between 20 to 35 years with the mean age $34.5 \pm 10.02 \%$ years, more than two thirds of staff nurses had nursing diploma and married, and about half of nurses had 1 to 15 years' experience in nursing the with the mean score $15.7 \pm 10.3$ years.

Concerning the total score of work environment scale among studied nurses in Port-Said general hospitals. It was found that less than half of staff nurses were moderately satisfied with their work. This finding was matching with (Curtis, Bowen, \& Reid, 2007). The finding of this study revealed that about half of staff nurses reported that they never experiencing or witnessing violence behaviours' as raising eyebrows or rolling eyes at another co-worker, while the minority $(2.3 \%)$ of them reported experiencing or witnessing harshlycriticizing someone without having heard both sides of the story daily 
within the last twelve month. The current study finding is not in the same line with (Alyileili, \& Chadwick, 2013) who reported that, more than half of nurses never exposed to harshly judged or criticized.

As well, the current study finding illustrated that more than two fifths of staff nurses never experiencing or witnessing irritablewith a co-workers within the last twelve month. Also, slightly less than two fifths of nurses reported that, they never experienced belittling or making hurtful remarks to or about co-workers most of nurses indicated that they had experienced horizontal violence, and they reported that this occurred frequently, as much as daily.

Mendez, (2011) in his study on nurses reported that all nurses recognized horizontal violence in their work experiences; some had witnessed these negative behaviors between other nurses while other participants had been targets for it. Moreover, Sheridan-Leos, (2008) conducts a study on 511 nurses and found that $31 \%$ of respondents reported being exposed to negative behavior as bullying at work place. Thomas and Burk, (2009) mentioned that the most negative behavior the nurses exposed to is experiencingstatements that were rude, abusive, humiliating or involved unjust criticism. Otherwise, Alyileili and Chadwick, (2013) noticed that, 48.0\% of nurses never experienced sworn, shouted or yelled at them.

As regard to the effect of horizontal violence among the staff nurses within the last 12 months at their workplace, it was found that less than half of nurses sometime felt dispirited due to decreased constructive criticism "feedback", and never talk about things that considered as a mistakes due to the feeling of terror. Furthermore, more than two fifth of them never wavered to questiondue to feeling of terror, they would be deridedsensation as negativerelated to themselves due tocommunications with coworkers, and more than one third sometimes had physical symptoms such as inability to sleep, headaches, and abdominal pain because of poor interactions with certain coworkers.

This finding was reported by many study, as horizontal violence can results in reduction in confidence or self-esteem (Bartholomew, 2006), anxiety, and sleeping disorders (Sheridan-Leos, 2008). Physical symptoms, such as weight gain or loss, hypertension and irritable bowel syndrome (Rowell, 2006). Moreover, Thomas and Burk, (2009) found that continued exposure to the horizontal violencebehaviors drains nurses of their enthusiasm for theprofessions. 
Additionally, it was found that staff nurses never have wavered to questiondue to terror. Also, less than half of nurses reported that they were never haven't talkregardingthings that they believe it was a mistake or error. This finding congruent with (Smith, Andrusyszyn and Spence Laschinger, 2010) who stated that nurses haven't talk daily related to they thought. Concerning healthcare workers exhibiting the negative behaviors, moreover the commoncommitters of horizontal violence considered to be supervisors, nurses' aids, physicians, other services such as housekeeping, security, secretarial, maintenance.

In this regard, Mendez, and Therese, (2011) mentioned that none of the nurses included in his study reported that horizontal violence was related to coercionamong healthcare providers. The occurrence of Tension between medical doctors and staff nursesmay lead to strengthen these negative behaviors like violence. Moreover Top managerial authority and their practices may be a directiveapproach toward anger and negative feelings of the workers. In addition to, Alyileili, and Chadwick, (2013) reported that healthcare workers exhibiting the negative behaviors was as following more than one third of doctors, about one fifth of supervisors, less than one fifth registered and staff nurses, minorities administrative staff, housekeeping staff, and assistant nurses.

Also, Bloom, (2018) reported that, the majority of the nurses reported horizontal violence from a peer or fellow nurse. Physicians and manager/administrators were also identified as exhibiting this type of behavior. Other health care providersand relatives of patients also were displayingat this attitude, patients were found to participate in these behaviors and a small percentage reported that others were responsible.

In relation to correlation between work environment and horizontal violence. It was found that there was astatistically significant positive correlation between total score of work environment and horizontal violence. Moreover, astatistically significant correlation was found between horizontal violence and 4 subscale of work environment as nurse participation, nursing foundation for quality of care, efficiency and head managers of nursing and support nurses, the adequacy of human resources and sources.

Longo and Sherman, (2007) clarified that negative workplace relationships candisruptgroupactivity, producing a climate of psychological pressure that can lead to burnout, increased staff turnover, and poor patient outcomes. In addition to Thomas and 
Burk, (2009) who asserted that the novel employed staff nurseshave experiencing horizontal violencethat may face a difficulty in achieving success in their new workplace.

\section{CONCLUSION}

The study concluded that, an average favorable work environment as reported by studied staff nurses. Slightly less than half of the sample reported that never exposure to horizontal violence.There was a statistically positive significant correlation between horizontal violence and total score of work environment. As well, strongly statistically significant correlation between horizontal violence and subscales of work environment as nurse participation, efficiency and head managers of nursing and support nurses, and the adequacy of human resources, except Working relationships between nurses and doctors subscale.

\section{RECOMMENDATIONS}

\section{Based upon the finding of the study, the following can be recommended:}

\section{Hospital management}

- Establishing and enforcing implement restricly ethical behaviors policies and procedures is very crucial to maintain zero tolerance environments related to $\mathrm{HV}$.

- Fostering organizational culture that create respectful work environment is a main responsibility of healthcare organization.

- Orient Managers need to be able to about identify the indicators of horizontal violence.

\section{Training}

- Health care organizations should implement various educational strategies to educate nurses and raise their awareness of problems of $\mathrm{HV}$.

- Educational sessions on horizontal violence \&organization's rulesmust be presented in the stage of staff orientation.

\section{Education and nursing faculties}

- Courses related work environment and HV should be designed and integrated in under-graduates curriculum.

- Increase awareness of nurses regarding ethical obligation to the nursing profession and patients is very essential to deal with unethical conduct.

\section{Research}


- Future research about factors elevating the rate horizontal violence and programs and strategies on how to overcome it.

\section{REFERENCES}

Akien, L., Clarke, S., Sloane, D., Sochaliski, J., Busse, R., Clarke, H., \& Shamian, J. (2001). Nurses' report on hospital care in five countries. Health Affairs, 20(3), 43-53.

Alyileili, A.K., \& Chadwick, C. (2013). Lateral violence among registered nurses working in government hospitals of UAE. Faculty of Education, The British University in Dubai, Available at: http://bspace.buid.ac.ae/bitstream/1234/703/1/100072.pdf.

American association of critical care nurses (2021). [online] Available at: $<$ https://www.aacn.org/nursing-excellence/healthy-work-environments> [Accessed 28 June 2021].

Attia, A., Abo Gad, R. \& Shokir, M. (2020). Workplace bullying and its effect on staff nurses' work engagement. Tanta Scientific Nursing Journal, 18(1), 83-109.

Aujla, S., (2012). Exploring the structural tenets of workplace incivility, published Master thesis, faculty of graduate studies, Guelph University.

Bartholomew, K. (2006). Ending nurse-to-nurse hostility. Marblehead, MA: HCPro.

Bloom, E. (2018). Horizontal violence among nurses: Experiences, responses, and job performance. Nursing Forum, 54(1), 77-83.

Curtis, J., Bowen, I., \& Reid, A. (2007). You have no credibility: Nursing students' experiences of horizontal violence. Nurse Education in Practice, 7(3), 156-163.

Labour.gov.on.ca. (2021). Workplace Violence and Workplace Harassment | Ministry of Labour. [online] Available at: $<$ https://www.labour.gov.on.ca/english/hs/topics/workplaceviolence.php> [Accessed 28 June 2021].

Longo, J. \& Sherman, R., (2007). Leveling horizontal violence. Nursing Management, 38(3), 34-37.

Longo, J. \& Smith, M., 2011. A Prescription for Disruptions in Care. Advances in Nursing Science, 34(4), pp.345-356.

Longo, J., \& Sherman, R. (2007): Leveling horizontal violence. Nursing Management, $38(3), 34-37,50-51$.

Longo, J., \& Smith, M.C. (2011). A prescription for disruptions in care: community building among nurses to address horizontal violence. Advances in Nursing Science, 34(4), 345-356. 
McKenna, B., Smith N., Coverdale J (2003). Horizontal violence: experiences of Registered Nurses in their first year of practice, Journal of Advanced Nursing, 42(1), 90-96.

McKenna, B., Smith, N., Poole, S. \& Coverdale, J. (2003). Horizontal violence: experiences of Registered Nurses in their first year of practice. Journal of Advanced Nursing, 42(1), 90-96.

Mendez, M., (2011). Horizontal Violence in the Nursing Work Environment: Beyond Oppressed Group Behavior, Published $\mathrm{PhD}$, thesis in Philosophy in Curriculum and Instruction, School of Public Health, University of New Orleans.

Mendez, T. M., (2011)."Horizontal Violence in the Nursing Work Environment: Beyond Oppressed Group Behavior". University of New Orleans Theses and Dissertations. 1377. https:/scholarworks. uno.edu/td/1377

Occupational safety and health act. (2012). Prevention workplace violence and harassment. Retrieved from http://www.joint commission.org/assets/1/18/SEA_40.

Pierre, ST., (2014). Understanding the management of inter/intra professional progression. Published master thesis. Faculty of sciences, Ottawa University. Canada.

Randle, J. (2003). Bullying in the nursing profession. Journal of Advanced Nursing, 43(4), 395-401.

Rowell, P., (2006). Being a "target" at work: Or William Tell and how the apple felt. Journal of Nursing Administration, 35(9), 377-379.

Sheridan-Leos, N., 2008. Understanding lateral violence in nursing. Clinical Journal of Oncology Nursing, 12(3), 399-403.

Smith, L., Andrusyszyn, M. \& Spence Laschinger, H. (2010). Effects of workplace incivility and empowerment on newly-graduated nurses' organizational commitment. Journal of Nursing Management, 18(8), 1004-1015.

Taylor, R., (2016). Nurses' perceptions of horizontal violence. Global Qualitative Nursing Research, 3, 233339361664100.

Thobaben, M., (2007). Horizontal Workplace Violence. Home Health Care Management \& Practice, 20 (1), 82-83.

Thomas, S. \& Burk, R. (2009). Junior nursing students' experiences of vertical violence during clinical rotations. Nursing Outlook, 57(4), 226-231.

Thomas, S., (2003). 'Horizontal Hostility'. AJN, American Journal of Nursing, 103(10), 87-88. 
Vessey, J., Demarco, R. \& Difazio, R. (2010). Bullying, harassment, and horizontal violence in the nursing workforce. The state of the science. Annual Review of Nursing Research, 28(1), 133-157.

\section{العلاقة بين بيئة العمل والعنف الأفقي بين طاقم التمريض بمستشفيات العامة ببورسعيد مى خالا السيد، سماح فيصل فكرى ، مروة مجمد عبد العليم}

\section{الخلاصة}

الخلفية: يعتبر العنف من التحديات الرئيسية في مهنة التمريض وجميع مؤسسات القطاع الصحي وقد يعيق تحقيق الاهداف المرجوه فى بيئة العمل الصحى. الهرف: هدفت الدراسة الحالية إلى تقييم العلاقة بين بيئة العمل والعنف الأفقي بين طاقم التمريض في المستشفيات العامتببورسعيد. التصميم: تم استخدام تصميم بحث وصفي ارتباطى. المكان: العمل بمستشفى بورسعيد العام ومستشفى الزهور العام ومستشفى بورفؤاد العام. العينة: عينة من 300 ممرضة تعمل في الأماكن الدذكورة أعلاه. الأدوات: تم جمع البيانات باستخدام أداتين: مؤشر عمل الممرضات

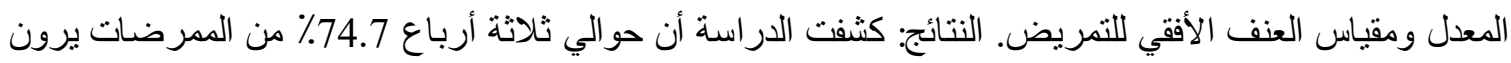

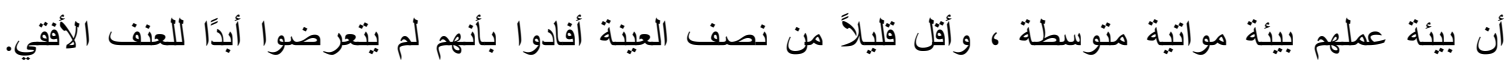

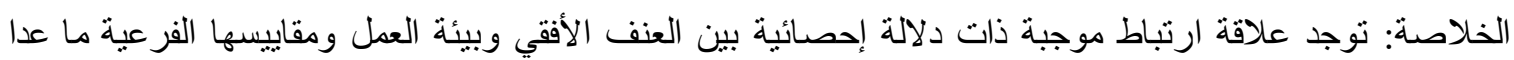
علاقات العمل بين الممرضات و الممرضات ونطاق الأطباء. التوصيات: إن وضع وتتفيذ سياسات وإجر اءات السلوك الأخلافي المقيدة أمر بالغ الأهية للحفاظ على بيئات عدم التسامح المتعلقة بالعنف الأفقي. 